\title{
Parametric Analysis of Leachate and Water Resources around Municipal Solid Waste Landfill area in Solan
}

\author{
Deepika Sharma ${ }^{1, a}$ and Rajiv Ganguly ${ }^{1}$ \\ ${ }^{1}$ Department of Civil Engineering, Jaypee University of Information Technology, Waknaghat, District Solan, Himachal Pradesh 173234, \\ India.
}

\begin{abstract}
Leachate is defined as the liquid that drains from the landfill. The paper presents the physico-chemical, bacteriological and heavy metal testing results carried out for leachate, surface and sub-surface water samples collected from municipal solid waste landfill and different water sources in Solan to find out the effect of leachate percolation on groundwater quality. Physico-chemical parameters analysed were, $\mathrm{pH}$, Total Dissolve Solid (TDS), sulphate, turbidity, Electrical Conductivity (EC) while biological parameters tested were Biological Oxygen Demand (BOD), Chemical Oxygen Demand (COD), Most Probable Number (MPN) test and ammonical nitrogen. Testing for heavy metals $(\mathrm{Pb}, \mathrm{Zn}, \mathrm{Cr}, \mathrm{Ni}, \mathrm{Fe})$ were carried out and have been reported. The results reveal that the leachate from the unlined landfill may have a significant impact on the groundwater resource (often used as drinking source) particularly because of the toxic nature of the leachate coupled with the soil characteristics which is permeable in nature.
\end{abstract}

Key words: Groundwater, Heavy Metals, landfill, leachate, municipal solid waste, Solan

\section{Introduction}

Municipal Solid Waste (MSW) includes the solid waste generated by households, commercial sectors, industries and institutions. Improper management and disposal have adverse effect on the environment and human health. This leads to many serious problems including ground water contamination and to a lesser extent surface water sources.

Open landfill dumps are the most conventional and most preferred way of disposing of solid waste in developing countries as it is simple, cheap and highly cost effective [1]. In India, in recent years, a number of alternate methods for managing and disposing of generated solid waste have been in operation but open dumping is still the most common method of solid waste disposal. These are often unmanned sites and bad odour and aesthetic problems often associated with these dump site. Further, insects, rodents, snakes and scavenger birds are potential carriers of human health related diseases. These sites also produce huge volumes of dust and high noise intensities. Effective management of solid wastes is a global issue, particularly in developing countries, as less resources, high population growth rate, and rapid waste disposal. [23]. Further, in an Indian context, majority of these landfills are non-engineered landfills and thereby proper lining of these landfills are absent. Further, most of the MSW generated is often organic in nature and in tropical conditions they get dissolved in rainwater and percolate into the ground thereby polluting the ground water sources. In recent times, the impact of leachate on groundwater and other water resources has been studied in details because of its immense environmental impact [4]. Leachate migration from wastes dump sites, release toxic pollutants and pose a great threat to water resource (both surface and sub surface sources) if not properly managed. The problem is more severe for unlined landfills.

Leaching of inorganic and organic pollutants from solid waste dump site depend on different factors including $\mathrm{pH}$, temperature, moisture content, type and properties of soil, hydrology of the area and the rate of progress through these stages is dependent on the physical, chemical and microbiological conditions developed within the landfill with time [5]. Due to excessive use of water resources, pollution from a large number of sources compounded by leaching of toxic chemicals from leachate to surface and groundwater surfaces.

The purpose of the study is to analyze the leachate, groundwater and surface water samples collected from

\footnotetext{
a Corresponding author: deepikasharmacivi189@yahoo.com
} 
solid waste dump site to determine the potential of leachate polluting the surrounding water bodies.

\subsection{Study area}

Salogra solid waste dump site is located near about $07 \mathrm{~km}$ form Solan district. The district lies between North latitude $30^{\circ} 44^{\prime} 53^{\prime \prime}$ to $31^{\circ} 22^{\prime} 01^{\prime \prime}$ and East longitude $76^{\circ} 36^{\prime} 10^{\prime \prime}$ to $77^{\circ} 15^{\prime} 14^{\prime \prime}$ and is covered by Survey of India degree-sheets 53A, 53B, 53E and 53F. The population of the district is 5, 76,670 (2011 census), of which 2, 70,291 (54\%) males, 2, 30,266 (46\%) female, sex ratio $(\mathrm{F}: \mathrm{M})$ is $884: 1000$ and density of population is 300 per sq km. Dump site spreads over an area of 3 acres. About 1.5 acre is used as dump site and remaining area is used as office and recycling plant. Waste is collected from 132 collection points from the Solan, Nalagarh, Arki and Kandaghat sub-divisions. Solid waste generated by Solan district is of the order of 22.5 tons per day. Soil is generally sandy loam in valley areas of the district. Figure 1 shows the location of the dumpsite.

\subsection{Sampling and analysis of samples}

Leachate samples have been collected from waste dumpsite in September 2015. Groundwater sample has been taken from the hand pumps near the waste disposal sites and surface water samples have also been collected. Samples have been collected in polyethylene and glass bottles. All samples were properly labelled with details of the source, date of sampling, time of sampling and address. Sample for bacteriological parameters were collected in sterilised bottle. The samples were transported to the laboratory, stored at $4{ }^{\circ} \mathrm{C}$ and analyzed within 24 hours for relevant parameters according to internationally accepted procedures and standard methods [6]. The concentrations of heavy metals were determined using an atomic absorption spectrophotometer

\section{Physico-chemical and bacteriological characteristic of samples}

The results of the analysis of the leachate sample have been presented in Table 1 and Table 2. Tables 3 and 4 present the parametric results for surface and groundwater.

Table 1. Results of testing for leachate samples for physicochemical parameter.

\begin{tabular}{|c|c|c|}
\hline S.no & Parameter & Results \\
\hline 1 & Conductivity $(\mathrm{EC}) \mu \mathrm{mho} / \mathrm{cm}$ & 2960 \\
\hline 2 & $\mathrm{pH}$ & 7.41 \\
\hline 3 & TDS & 1968 \\
\hline 4 & Sulphate $(\mathrm{mg} / \mathrm{l})$ & 50 \\
\hline 5 & Nitrate $(\mathrm{mg} / \mathrm{l})$ & 27 \\
\hline 6 & Ammonical nitrogen $(\mathrm{N})(\mathrm{mg} / \mathrm{l})$ & nil \\
\hline 7 & BOD at $27^{0} \mathrm{c} 3$ day & 2300 \\
\hline 8 & COD $(\mathrm{mg} / \mathrm{l})$ & 7150 \\
\hline
\end{tabular}

\section{Materials and methods}

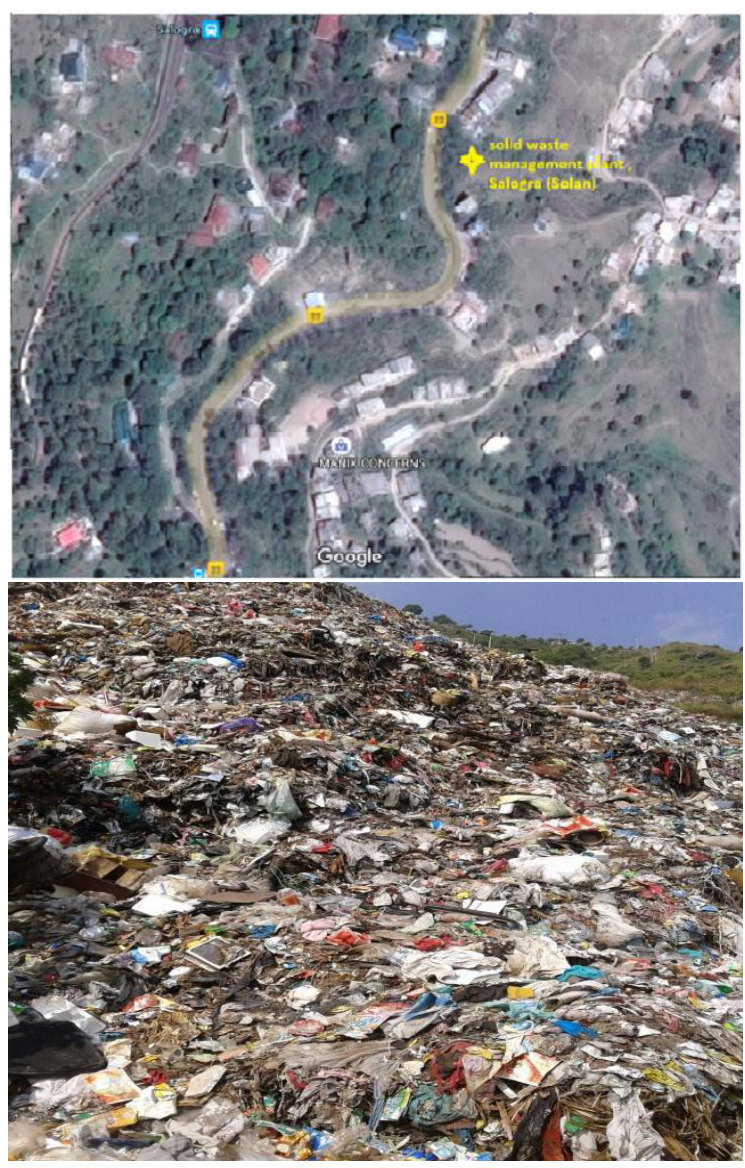

Figure 1: solid waste management plant, Salogra (Solan)

Table 2. Results of testing for leachate samples for heavy metals

\begin{tabular}{|c|c|c|}
\hline S.no & Parameter (heavy metal) & Results \\
\hline 1 & Lead $(\mathrm{mg} / \mathrm{l})$ & 0.035 \\
\hline 2 & Zinc $(\mathrm{mg} / \mathrm{l})$ & 0.084 \\
\hline 3 & Chromium $(\mathrm{mg} / \mathrm{l})$ & BDL \\
\hline 4 & Nickel $(\mathrm{mg} / \mathrm{l})$ & 0.017 \\
\hline 5 & Iron $(\mathrm{mg} / \mathrm{l})$ & 0.210 \\
\hline
\end{tabular}

The $\mathrm{pH}$ for leachate sample was found to be between 7.4, for groundwater 7.41 and for surface water 8.28. All leachate samples have high concentration of dissolved solids. The total dissolved solid was found $1968 \mathrm{mg} / 1$ in leachate. In groundwater samples dissolved solid concentrations were $242 \mathrm{mg} / \mathrm{l}$ and in surface water was $389 \mathrm{mg} / \mathrm{l}$. The BOD value reported was $2300 \mathrm{mg} / \mathrm{l}$ and the COD value obtained was $7150 \mathrm{mg} / \mathrm{l}$. High COD concentrations represents higher amount of inorganic matter present in the leachate sample. The BOD/COD ratio was found to be 0.32 which means that substantial portion of the organic matter is biodegradable. 
Table 3. Results of testing for Surface \& ground water samples physicochemical parameters

\begin{tabular}{|c|c|c|c|c|c|}
\hline S.no & Parameter & $\begin{array}{c}\text { Result } \\
\text { (surface } \\
\text { water) }\end{array}$ & $\begin{array}{c}\text { Result } \\
\text { (Ground } \\
\text { water) }\end{array}$ & $\begin{array}{c}\text { Acceptable } \\
\text { Limits } \\
\text { (WHO) }\end{array}$ & $\begin{array}{c}\text { Permissible limits } \\
\text { (WHO) }\end{array}$ \\
\hline 1 & $\mathrm{pH}$ & 8.28 & 7.41 & $6.5-8.5$ & No relaxation \\
\hline 2 & TDS & 389 & 242 & 500 & 2000 \\
\hline 3 & Sulphate $(\mathrm{mg} / \mathrm{L})$ & 18 & 63 & 200 & 400 \\
\hline 4 & Nitrate $(\mathrm{mg} / \mathrm{L})$ & 0.15 & $\overline{B D L}$ & 45 & No relaxation \\
\hline 5 & $\begin{array}{c}\text { Ammonical nitrogen }(\mathrm{N}) \\
(\mathrm{mg} / \mathrm{L})\end{array}$ & nil & nil & - & - \\
\hline 6 & BOD at $27^{0} \mathrm{c} 3$ day $(\mathrm{mg} / \mathrm{L})$ & 6.2 & Nil & - & 30 (surface water) \\
\hline 7 & $\mathrm{COD}(\mathrm{mg} / \mathrm{L})$ & 20 & Nil & - & 250 (surface water) \\
\hline
\end{tabular}

Table 4. Results of testing for Surface \& ground water samples for heavy metals

\begin{tabular}{|l|l|l|l|l|l|}
\hline S.no & Parameter & $\begin{array}{l}\text { Result } \\
\text { (surface water) }\end{array}$ & $\begin{array}{l}\text { Result } \\
\text { (ground water) }\end{array}$ & $\begin{array}{l}\text { Acceptable limits } \\
\text { (WHO) }\end{array}$ & Permissible limits (WHO) \\
\hline 1 & Lead $(\mathrm{mg} / \mathrm{L})$ & 0.024 & 0.027 & 0.01 & No relaxation \\
\hline 2 & Zinc $(\mathrm{mg} / \mathrm{L})$ & 0.014 & 0.018 & 5 & 15 \\
\hline 3 & Chromium $(\mathrm{mg} / \mathrm{L})$ & BDL & BDL & 0.05 & No relaxation \\
\hline 4 & Nickel $(\mathrm{mg} / \mathrm{L})$ & 0.006 & 0.002 & 0.02 & No relaxation \\
\hline
\end{tabular}

It was interesting to note that no BOD and COD concentrations were reported for groundwater samples. BOD and COD concentrations determined for samples collected from surface water sources showed also minimum concentrations and were well within permissible limits. However, the results do not give any indication of the contribution from leachate.

In case of heavy metals, lead concentrations were higher than permissible limits for all samples collected. The reported results were $0.035 \mathrm{mg} / \mathrm{l}$ in leachate sample, $0.024 \mathrm{mg} / 1$ for surface water and $0.027 \mathrm{mg} / 1$ for ground water Lead is known to cause serious conditions such as anemia, brain damage and kidney failure. Further, because of size and charge similarities, lead can substitute for calcium and can be deposited in bones; children are especially susceptible to this effect. The concentration of chromium in leachate, surface and groundwater was found below the detection limit (BDL). The WHO recommended limit for $\mathrm{Cr}$ in drinking water is 0.05 $\mathrm{ppm} / \mathrm{lt}$. The leachate sample tested reported $\mathrm{Cr}$ concentration of $0.017 \mathrm{mg} / \mathrm{l}$, whereas it was reported to be $0.006 \mathrm{mg} / 1$ for surface water and $0.002 \mathrm{mg} / \mathrm{l}$ for groundwater. Zinc is a trace element that is essential for human health. In less quantities absorbed it can lead to loss of appetite, decreased sense of smell and slow healing of wounds. The concentration of Zinc in leachate was to be found $0.084 \mathrm{mg} / 1,0.014 \mathrm{mg} / \mathrm{l}$ in surface water and $0.018 \mathrm{mg} / \mathrm{l}$ for groundwater. Hence, for all the samples the concentrations were well within the permissible limits prescribed by WHO [7].
Concentration of sulphate was determined to be $50 \mathrm{mg} / \mathrm{l}$ for leachate sample and $18 \mathrm{mg} / 1$ and $63 \mathrm{mg} / \mathrm{l}$ for surface water and groundwater respectively. All result reveals that the concentration of sulphate in groundwater was higher as compared to leachate and surface water due to same natural sources. Nitrate concentrations in leachate sample were determined to be $27 \mathrm{mg} / 1$ and $0.15 \mathrm{mg} / 1$ in surface water. It was $\mathrm{BDL}$ for groundwater source. Ammoniacal nitrogen $(\mathrm{N})$ was nil for all samples.

Results for E.Coli and fecal coliform testing results for the samples have been presented in Table 5 and Table 6 for leachate and groundwater samples.

Table 5. Results of testing of biological examination for leachate samples

\begin{tabular}{|c|c|c|}
\hline S.no & Parameter & Results \\
\hline 1 & E.coli & $2500 / 100 \mathrm{ml}$ \\
\hline 2 & Fecal Coliforms & $3000 / 100 \mathrm{ml}$ \\
\hline
\end{tabular}

Table 6 Results of testing for hand pump water samples

\begin{tabular}{|c|c|c|}
\hline S.no & Parameter & Results \\
\hline 1 & E.coli & Absent \\
\hline 2 & Fecal Coliforms & Absent \\
\hline
\end{tabular}

Result of coliform testing showed that the leachate contained high concentration of E.Coli and fecal coliforms whereas they were absent for both surface and ground water samples. A similar study conducted in Turmuri, Belgaum reported that samples lying within the 
$500 \mathrm{~m}$ from landfill area were contaminated with E-Coli bacteria as it exceeds the prescribed limits of BIS and WHO standards with the number in $1600,160,0300$ per $100 \mathrm{ml}[8]$.

\section{Conclusion}

In this study, leachate, surface and groundwater samples were collected from waste dump site to find out the effect solid waste on the groundwater quality. Samples were collected from hand pumps, surface water body and leachate from waste dump site in sampling bottles and different physico chemical parameters were analysed. The concentrations of metals were determined with the instruments like; AAS. The results of this study revealed that metal concentration, BOD, COD was high in all of the leachate samples. In comparison, very low values were reported for groundwater and surface water samples. Zn concentration was within the WHO limits for all the samples. However, high concentration of lead was observed in surface and groundwater and exceeded the

\section{REFERENCES}

1. A. Barrett, J. Lawlor The Economics of Waste Management in Ireland, Economic and Social Research Institute, Dublin (1995).

2. S.J. Cointreau Environmental management of urban solid wastes in developing countries: A project guide, Urban Development Dept, World Bank, Retrieved June 27, 2009 from http://www.worldbank.org/html/fpd/urban//solidwm/techpaper5.pdf.(1982).

3.P.L. Doan Institutionalizing household waste collection: the urban environmental management project in Cote d'Ivoire. Habitat Int., 22, 1, 27-39 (1998) 4. S. Mor, K. Ravindra, R.P. Dahiya, A. Chandra A Leachate Characterization and assessment of groundwater pollution near municipal solid waste landfill site. Environ. Monit. Assess., 4, 325-334 (2006)
WHO recommended value. Chromium was also found in all samples collected from groundwater \& surface water in some samples the concentration of chromium was higher. E.coli and fecal coliforms was present in leachate samples but absent in groundwater\& surface water show the presence of fecal matter in waste.

From the results, it can be concluded that the metals present in solid waste can migrate into groundwater and pollute it and contribute to degradation of land, water and air. So, there is a need to change in land use pattern and to adapt new methods for waste utilization. The countries like U.S, Germany, UK, Denmark and Netherlands have many alternatives for disposal and recycle and reuse of municipal solid waste. Use of organic waste as manure in agriculture provides a feasible alternative for its safe disposal and improves soil environment and crops production. However, a judicious amendment strategy has to be developed to abate the land and water pollution from the pollutants presents in it.

5. F.G. Pohland, S.R Harper Critical Review and Summary of Leachate and Gas Production from landfills, US Environmental Protection Agency, Cincinnati; EPA/600/2-86/073 (1985)

6. Standard Methods for the Examination of Water and Wastewater, American Public Health Association (APHA), American Water Works Association (AWWA), Water Pollution Control Federation (WPCF). 16th edition, American Public Health Association, Washington, DC, U.S.A (2010)

7. WHO. Guidelines for Drinking Water Quality. (World Health Organization Recommendation, Geneva $3^{\text {rd }}$ Edn. Vol. 1, 515, 2004)

8. C. Patil, S. Narayanakar, A. Virupakshi Assessment of Groundwater Quality Around Solid Waste Landfill Area A Case Study. Int J Innov Res Sci, Eng and Tech 2, 7, 3131-3136 (2013) 